\title{
Preventing injuries in public playgrounds through partnership between health services and local authority: community intervention study
}

\author{
J R Sibert, Alison Mott, Kim Rolfe, Rosie James, Rupert Evans, Alison Kemp, F D J Dunstan
}

Public playgrounds are important for children's play and development. Safety is a prime concern not only to prevent injuries but also because families need the assurance that it is safe for their children to play. ${ }^{1}$ One way of improving safety is for health services and local authorities to form a partnership in the surveillance of injuries and the making of improvements. We report the results of such a partnership in Cardiff. ${ }^{3}$

\section{Participants, methods, and results}

Children injured in public playgrounds in Cardiff were identified from the accident and emergency department and linked to the playground, equipment, and surface. We estimated exposure of children to injuries from the numbers of children recorded to be playing in individual playgrounds by inspectors visiting them at random as part of their work. ${ }^{3}$ From this information we calculated injury rates per observed child.

In June and July 1995 the council made several changes to its largest playgrounds on the basis of our surveillance programme. ${ }^{23}$ A greater depth of bark (600 mm instead of $300 \mathrm{~mm}$ ) was introduced in Roath Park and the four other large playgrounds in the north area of the council's sports and leisure department. This was because of the pattern of arm fractures from falls we had found in our previous studies..$^{2}$ In Roath Park monkey bars (overhead horizontal ladders) were replaced by a rope climbing frame. This was because the fracture rate for monkey bars was twice that for other climbing frames. We used as controls the 14 playgrounds surfaced with bark and the four surfaced with rubber in the two other areas in Cardiff (west and south east) where the council had not made any changes during 1994-6.

We assumed a Poisson model for the injury rate, and we compared injuries and the injury rate per observed child in the 18 months before and after the changes were implemented and between the three groups of playgrounds. Exposure data for the control playgrounds in the second 18 months were patchy, and we have assumed that usage was unchanged. Data from the playgrounds with good exposure data showed that usage remained roughly constant throughout the study, and we have therefore assumed this where data were limited.

The changes we made did not lessen the popularity of the playgrounds, and no injuries were recorded for the rope climbing frame. The table shows that the injury rate per observed child was significantly reduced in the five playgrounds where changes had been made. There were also significant differences when Roath Park was taken on its own but not with the four playgrounds with changes to bark depth alone.

In assessing our surveillance system we compared for 1994- 6 the children ascertained by us with those reported to the council. In 1994, 152 injuries were recorded by our surveillance system and 33 by the council's reporting system. In 1995 the numbers were respectively 113 and 12 and in 1996,112 and 20. There are clear differences.

\section{Comment}

We believe that our surveillance programme has contributed to playground development and safety in Cardiff. We were concerned that replacement of monkey bars and the introduction of other safety measures would make playgrounds less popular, but this was not the case. This surveillance programme and partnership is comparatively simple to apply. It does not need expensive resources, and it could be introduced widely. ${ }^{4}$

We thank all the staff of the sports and leisure department and of the accident and emergency department for all their help with this work.

Contributors: JRS was concerned with planning, supervision, and analysis and is guarantor for the study. AM was concerned with planning, supervision, and analysis. KR was responsible for managing the database. $\mathrm{RJ}$ obtained data on exposure and liaised with Cardiff County Council. RE liaised with the accident and emergency department. FDJD was responsible for statistical analysis. Kenneth Kemp, emeritus professor and honorary senior research associate, was responsible for statistical analysis at the beginning of our work on playground injuries.

Funding: The early part of our work on playground injuries was partly funded by the chief medical officer's research budget at the Welsh Office and by the Catherine Jenkins Memorial Trust.

Competing interests: In 1998, after the period of this study, we had limited funding for our surveillance programme from playground equipment manufacturer (Hags Play, Sturminster Newton, Dorset).

1 Heseltine P, Holborn J, Wenger J. Playground management and safety. London: National Playing Fields Association, 1989.

2 Mott A, Evans R, Rolfe K, Potter D, Kemp KW, Sibert JR. Patterns of injuries to children on public playgrounds. Arch Dis Child 1994;71:328-30.

3 Mott A, Rolfe K, James R, Evans R, Kemp A, Dunstan FDJ, et al. Safety of surfaces and equipment for children in playgrounds. Lancet 1997;348:1874-6.

4 Stone DH, Morrison A, Ohn TT. Developing injury surveillance in accident and emergency departments. Arch Dis Child 1998;78:108-10.

(Accepted 18 December 1998)
Department of Child Health, University of Wales College of

Medicine, Academic Centre, Llandough Hospital, Penarth,

Vale of Glamorgan

CF64 2XX

J R Sibert, professor of community child health

Alison Mott, consultant paediatrician (community child health)

Kim Rolfe, research assistant Alison Kemp senior lecturer in community child health F D J Dunstan, senior lecturer in medical statistics Sports and Leisure Department, Cardiff County Council, Cardiff CF14 4EP Rosie James, principal landscape officer

Accident and

Emergency Department, University Hospital of Wales, Cardiff CF4 4XW Rupert Evans, consultant Correspondence to Professor Sibert sibert@cardiff.ac.uk

\section{BMJ 1999;318:1595}

Injuries and injury rates per observed child in playgrounds in Cardiff

\begin{tabular}{|c|c|c|c|c|c|c|}
\hline & \multicolumn{2}{|c|}{1 Jan 1994-30 June 1995} & \multicolumn{2}{|c|}{1 July 1995-31 Dec 1996} & \multicolumn{2}{|c|}{$P$ value } \\
\hline & $\begin{array}{c}\text { No of injuries } \\
\text { (fractures) }\end{array}$ & $\begin{array}{l}\text { Injury rate per } \\
\text { observed child }\end{array}$ & $\begin{array}{l}\text { No of injuries } \\
\text { (fractures) }\end{array}$ & $\begin{array}{l}\text { Injury rate per } \\
\text { observed child }\end{array}$ & $\begin{array}{c}\text { Before and } \\
\text { after changes }\end{array}$ & $\begin{array}{l}\text { Compared with } \\
\text { controls }\end{array}$ \\
\hline Playgrounds in north area with changes & $53(23)$ & 0.719 & $21(6)$ & 0.297 & $<0.001$ & $<0.03$ \\
\hline Roath Park (monkey bars and bark depth) & $31(13)$ & 0.929 & $11(4)$ & 0.271 & $<0.001$ & $<0.005$ \\
\hline $\begin{array}{l}\text { Control playgrounds in south east and } \\
\text { west area with no changes }\end{array}$ & $35(12)$ & 0.433 & $28(10)$ & 0.346 & - & - \\
\hline
\end{tabular}

